\title{
Dimorfismo sexual craniométrico em brasileiros
}

\author{
Ana F. C. Cardozo*, Luiz F. Júnior, João S. P. Neto, Marcelo C. Meneghim, Stéfany L. Gomes
}

\section{Resumo}

Objetivo - Verificar se as distâncias extracranianas apresentam dimorfismo sexual e criar um modelo matemático de regressão logística para a estimativa do sexo. Métodos - Foram estudadas onze medidas (1- Meato acústico externo ao gnátio, 2 - Meato acústico externo ao próstio, 3 - Meato acústico externo à espinha nasal anterior, 4 - Meato acústico externo à glabela, 5 - Meato acústico externo ao bregma, 6 - Meato acústico externo ao vértex, 7 - Meato acústico externo ao lâmbda, 8 - Meato acústico externo ao opistocrânio, 9 - Meato acústico externo ao ínio, 10 - Meato acústico externo ao mastoideo (lado esquerdo),11 - Meato acústico externo ao gônio) utilizando o Crâniometro de Galvão, em 200 crânios. Resultado - Foi concebido um modelo de regressão logística com 79,1\% de sensibilidade, 79,8\% de especificidade e $79,5 \%$ de acurácia. Conclusão - O método se mostra eficaz na predição do sexo e pode ser utilizado como ferramenta auxiliar em processos de identificação humana.

\section{Palavras-chave:}

Dimorfismo sexual, antropologia forense, odontologia forense

\section{Introdução}

A identificação humana é descrita por VANRELL (2015) como um conjunto de procedimentos diversos para individualizar uma pessoa ou objeto. Para tal fim, A INTERPOL dividiu os métodos de identificação em dois, sendo os primários: identificação de dentes (registros odontológicos), DNA (ácido desoxirribonucleico) e dactiloscopia. Estes podem levar diretamente a um indivíduo, diferente dos métodos identificação secundários, como a antropometria física e reconstrução facial. (FRANCESQUINI JR, et al. in DARUGE et al. Por meio da antropometria física, o objetivo desse trabalho foi verificar se as distâncias (onze medidas) extra cranianas a serem estudadas em ossos de crânios humanos apresentam dimorfismo sexual.

\section{Resultados e Discussão}

A amostra constou na análise de 200 crânios pertencentes ao Biobanco da FOP/UNICAMP, sendo 109 do sexo masculino (54,5\%) e 91 (45,5\%) do sexo feminino. Após a verificação das características gerais da amostra, os dados foram submetidos ao teste de Kolmogorov-Smirnov para constatar a normalidade dos dados.

Tabela 1. Estatística descritiva

\begin{tabular}{l|c|c|c|c}
\hline \multicolumn{1}{c|}{ Variáveis } & Média & Mínimo & Máximo & $\begin{array}{c}\text { Desvio- } \\
\text { Padrão }\end{array}$ \\
\hline MAE-GNÁTIO & 11,319 & 9,5 & 13,1 & 0,6933 \\
\hline MAE-PRÓSTIO & 9,466 & 7,9 & 11,5 & 0,6774 \\
\hline MAE-ENA & 9,283 & 7,9 & 11 & 0,5357 \\
\hline MAE-GLABELA & 9,929 & 5,2 & 12,1 & 0,6305 \\
\hline MAE-BREGMA & 12,342 & 10,5 & 114,4 & 7,2758 \\
\hline MAE-VÉRTEX & 12,6226 & 2,2 & 118,8 & 7,60384 \\
\hline MAE-LAMBDA & 10,666 & 9 & 12,8 & 0,6096 \\
\hline MAE- & 9,685 & 1,6 & 12,1 & 0,9568 \\
\hline OPSTOCRÂNIO & 7,62 & 1,8 & 9,8 & 0,7561 \\
\hline MAE-ÍNIO & 2,405 & 1,2 & 11,7 & 0,8105 \\
\hline MAE- & 5,93 & 2,4 & 7,8 & 0,7701 \\
\hline MAE-GÓNID-E & & & &
\end{tabular}

Ao se aplicar o teste $t$ foi constatada a aceitação da hipótese de que há diferenças entre os sexos nas variáveis MAE-GNÁTIO, MẢE-PRÓSTIO, MAE-ENA, MAE-GLABELA, MAE-LAMBDA, MAE-MASTÓIDE E e
MASTÓIDE-GÔNIO, pois o valor de $p<0,05$. Por outro lada para as variáveis MAE-BREGMA, MAE-VÉRTEX, MAE-OPISTOCRÂNIO, MAE-ÍNIO, como o valor de $p>0,05$ não foi constatado dimorfismo sexual. Foram testadas as onze variáveis do estudo e, aplicando-se a regressão logística pelo método de Stepwise-Forward Wald. Após a aplicação do teste de Correlação de Pearson para as variáveis selecionadas pelo teste de Regressão Logística foi observada uma correlação significante para todas as variáveis, apresentando uma correlação forte ao nível de $p=0,01$.

\section{Logito $=-26,064+0,855^{\star} M A E-G N A ́ T I O+0,886 \star M A E-$ GLABELA + 0,834*MAE-GÔNIO}

Tabela 2. Distribuição de frequência e percentagens corretas para predição do sexo.

\begin{tabular}{|c|c|c|c|c|}
\hline & & \multicolumn{3}{|c|}{ Previsto pelo modelo } \\
\hline & & \multicolumn{2}{|c|}{ Sexo } & \multirow{2}{*}{$\begin{array}{c}\text { Porcentagem } \\
\text { correta } \\
\end{array}$} \\
\hline & & Feminino & Masculino & \\
\hline \multirow[t]{2}{*}{ Sexo } & Feminino & 72 & 19 & 79,1 \\
\hline & Masculino & 22 & 87 & 79,8 \\
\hline \multicolumn{2}{|c|}{ Porcentagem global } & & & 79,5 \\
\hline
\end{tabular}

\section{Conclusões}

Conclui-se que das medidas estudadas, apenas MAEGNÁTIO, MAE-GLABELA e MASTÓIDE-GÔNIO podem ser consideradas dimórficas. A tabela 2 revela que 0 método resulta em $79,1 \%$ de sensibilidade, $79,8 \%$ de especificidade e $79,5 \%$ de acurácia, se mostrando eficaz na predição do sexo do que o mero acerto ao acaso, ou seja, valores maiores que 0,5 (cutoff), seriam considerados como "Masculino" e menores como "Feminino".

\section{Agradecimentos}

Agradeço a Universidade Estadual de Campinas, a Faculdade de Odontologia de Piracicaba, a Pró-Reitoria de Graduação pela bolsa de iniciação científica concedida através do PIBIC/CNPq-Graduação. 